\title{
SIGNIFICANCE OF SOCIAL CAPITAL IN DEVELOPING RELIGIOSITY AMONG UNIVERSITY STUDENTS
}

\author{
Tayyaba Sohail \\ Department of Sociology \\ University of Management and Technology, Lahore, Pakistan \\ Inam ul Haq \\ Department of Sociology \\ University of Management and Technology, Lahore, Pakistan \\ Dr. Riffat Munawar \\ Institute of Social and Cultural Studies, \\ University of the Punjab, Lahore, Pakistan
}

\begin{abstract}
Religiosity of an individual is depicted through the participation in congregational events. Such participation encourages production of social capital. Informal networks like family, peers and neighborhood are important production sources of social capital and are also prime sources to introduce religious teachings. The sources of social capital and religiosity are same. Therefore, the current paper examines the role of social capital in developing religiosity among youth. The qualitative study was conducted using purposive sampling. The sample is comprised of educated youth of Lahore. Twenty five in-depth interviews and 3 FGDs were conducted from an educational institution. The data analysis was done through themes and narratives. The findings suggest that the culture, environment and family are important contributors in the production of religiosity. Moreover, the labeling plays vital role in encouraging or discouraging religiosity. Conclusively the religious practices have lost spirituality and are becoming more superficial day by day.
\end{abstract}

Keywords: religiosity, social capital, reciprocity, social control, youth engagement

\section{Introduction}

The current paper examines the role of social capital in developing religiosity among youth, aged 15 to 24 (UNESCO; The United Nations Educational, Scientific and Cultural Organization). It analyses the impact of informal networks (family, friends and neighbors; essentials components of social capital) over the religious practices of individuals. Individuals are valued on the basis of their level of religiosity. Religiosity refers to the beliefs and practices, entailing to one's whole life, concerning to the supreme, ultimate and divine power. ${ }^{1}$ Considering the orientation, religiosity is

\footnotetext{
${ }^{1}$ Alicia and Torres, “An Interaction Model of Parents' and Adolescents' influences on Mexican Adolescents' Intentions for Contraception and Condom Use," (PhD. Thesis The University of Texas at
}

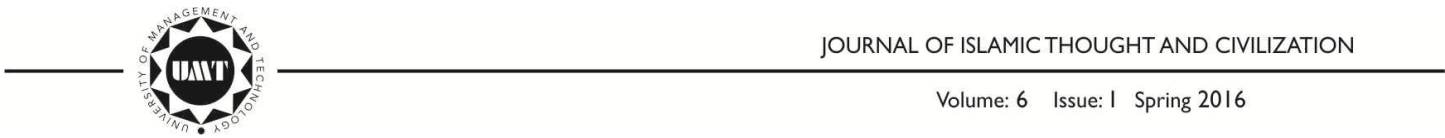




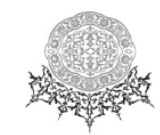

categorized into three types. Intrinsic refers to the "the religion that is lived." Individual lives to serve the religion with his services and sacrifice in the name of religion e.g. martyrs and saints. Extrinsic refers to the "religion that is used." This orientation keeps individuals to use religion as a mean to end. Religion is considered as instrumental and utilitarian in nature. Religion is also seen as a source to solve the complexities of the life thus, religiosity is also classified as "Religion as Quest.". Religiosity is a multi-dimensional approach. The construction of religiosity involves belief system (cognition), spiritual and physical commitment to rituals (affect), and ritual activities (behavior). ${ }^{3}$ Five dimensional approach of religiosity indicates basic religiosity, central duties, religious experience, religious knowledge and orthopraxis (everyday life of believers) as important indicators of religiosity. ${ }^{4}$

Individual's religiosity is considered an important factor as it is assumed that a religious person can encourage the whole family to practice religion in their regular lives and is beneficial for the society as a whole. Social capital also works for mutual benefits. Ibn-i-Khaldūn ${ }^{5}$ stated that religion is a significant factor of mutual cooperation and support among people. Religiosity doesn't only depend upon the individual faith but many other factors contribute in the development of religiosity like globalization, information, community engagement, communication, terrorism etc.

Social capital refers to the collectivism, networks, trust, cooperation, relationships and Mutually Beneficial Actions. ${ }^{6}$ Social Capital has structural (roles,

Austin, 2007); Antonia Darder, Culture and Difference: Critical Perspectives on the Bicultural Experience in the United States (New York: Greenwood Publishing Group), 1995; Yoo and Chung Russell, Religion and Spirituality in Korean America (Illinois: University of Illinois Press, 2009), 7577; W. D. Roof, "Concepts and Indicators of Religious Commitment: A Critical Review," in R. Wuthnow (ed.) The Religious Dimension: New Directions in Quantitative Research (London: Academic Press, 1979) 17-45; Margaret and Howard, Sociology: Understanding a Diverse Society, Updated (USA: Cengage Learning, 2007)

${ }^{2}$ Cragun Ryan, Introduction to Sociology (USA: Black Sleet River, 2006)

${ }^{3}$ Albrecht Marie, Cunningham, and Pitcher, "The Dimensions of Religiosity: A Conceptual Model with an Empirical Test," Review of Religious Research 27, no. 3 (1986): 226-244. https://www.jstor.org/stable/3511418?seq=1\#page_scan_tab_contents;_William H. Swatos, Encyclopedia of Religion and Society (Hartford: Rowman Altamira, 1998)

${ }^{4}$ Rodney Stark, Charles Y. Glock, "The New Denominationalism," Review of Religious Research 7, no. 1 (1965): 8-17.

${ }^{5}$ Ibn-i-Khaldun. The Muqaddimah: an Introduction to History, 1. Edited by Franz Rosenthal, and Nessim Joseph Dawood. No. 43. (Princeton: Princeton University Press, 1969)

${ }^{6}$ Pierre Bourdieu, "Social Space and Symbolic Power." Sociological Theory 7, no. 1 (1989): 14-25; James Coleman. "Social Capital in the Creation of Human Capital," American Journal of Sociology (1988), 95-120; Robert Putnam, Leonardi Robert, and Nanetti Raffaella, Making Democracy Work: Civic Traditions in Modern Italy (Princeton: Princeton University Press, 1994).

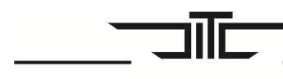

JOURNAL OF ISLAMIC THOUGHT AND CIVILIZATION 
rules, precedents and procedures) ${ }^{7}$ and cognitive (norms, values and beliefs) ${ }^{8}$ manifestations. ${ }^{9}$ Norms of trust and reciprocity reflects the quality of social capital which is fabricated through the networks of social relations (structure). The networks can be further characterized as formal and informal. ${ }^{10}$

In order to apply the concept of social capital at a practical and operational level, it is broken down into five key dimensions: (a) Groups and network (b) Trust and solidarity (c) Collective action and cooperation (d) Social cohesion and inclusion (e) Information and communication. ${ }^{11}$ Therefore, social capital is strongly dependent on rich durable networks which develop trust, knowledge sharing and a sense of reciprocity. However, this information and communication form the crux of Social interactions.

Social capital is generated through various sources like formal (Civil societies, charitable organizations, unions, associations etc.) and informal (family household, Family beyond the household, friends / intimates Neighbors) networks. ${ }^{12}$ The multiple dimensions of social capital are reflected by group characteristics, generalized norms, everyday sociability, togetherness, neighborhood connections, volunteerism and trust. $^{13}$

Hirschi's ${ }^{14}$ theory of social control also stresses upon the importance of social bond. It is assumed that strong "social bond" refrain individuals indulging in delinquent behaviors. Attachment (linkages), Commitment (investment of time and resources), involvement (participation) and beliefs are the comprising components of

${ }^{7}$ Hitt, et al. "The Importance of Social Capital to the Management of Multinational Enterprises: Relational Networks among Asian and Western Firms." Asia Pacific Journal of Management 19, no. 2-3 (2002): 353-372.

${ }^{8}$ Anirudh Krishna, and Uphoff Norman, "Mapping and Measuring Social Capital through Assessment of Collective Action to Conserve and Develop Watersheds in Rajasthan, India," The Role of Social Capital in Development (2002): 85.

${ }^{9}$ Norman Uphoff, and M. Wijayaratna Chandrasekera, "Demonstrated Benefits from Social Capital: the Productivity of Farmer Organizations in Gal Oya, Sri Lanka," World Development 28, no. 11 (2000), 1875-1890; Christiaan Grootaert and Bastelaer Thierry Van, eds. Understanding and Measuring Social Capital: A Multidisciplinary Tool for Practitioners. Vol. 1(Washington: World Bank Publications, 2002).

${ }^{10}$ Wendy Stone, "Measuring Social Capital," Australian Institute of Family Studies, Research Paper 24 (2001).

${ }^{11}$ Christiaan Grootaert, ed. Measuring Social Capital: An Integrated Questionnaire. No. 18.

World Bank Publications, 2004.

${ }^{12}$ Ibid.

${ }^{13}$ Deepa Narayan, and Cassidy Michael, “A Dimensional Approach to Measuring Social Capital: Development and Validation of a Social Capital Inventory," Current Sociology 49, no. 2 (2001): 59-102.

${ }^{14}$ Travis Hirschi, Causes of Delinquency (USA: Transaction publishers, 2002); Travis Hirschi, Travis, and J. Hindelang Michael, "Intelligence and Delinquency: A Revisionist Review," American Sociological Review (1977): 571-587.

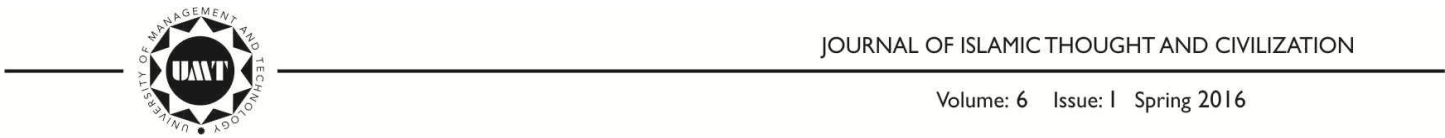




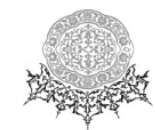

social bond. Thus, it can be assumed that social bonds and social capital also refrains individuals to exercise their choice of life freely.

\section{Conceptualization}

Religion is an important social institution. As it does not just provide the moral grounds for society's construction, but also provide guiding principles for the fabrication of relations. Thus, it acts as a tool of social control. Religion, culture and social construction of a society cannot be disintegrated. Religion provides manual for the making and sustaining of relationships and in return social relations hold religion as an important element of their lives. Religion is also an important source to strengthen cultural identity and connect people with each other, thus, providing sense of belongingness. Religion increases social solidarity and act as a unifying force in the society. ${ }^{15}$ Religion is a cultural system of shared beliefs of supernatural and thus provides a sacred reality. ${ }^{16}$

Man is introduced with the religion through families and later it is practiced along with the peers and neighborhood. Family, friends and neighborhood are an important source of a social capital generation. Like social capital, Religiosity is based on the trust and also encourages reciprocity. The religious reciprocity is based on the value/concept of taking return of good acts from God and maintaining good repute among social networks. The good rapport among network allows an exchange of benefits. Thus, social capital and religiosity are interlinked.

Families and religious institutions reflect their interdependency and inter linkages by "relationships of dependency and control." 17 The families socialize their children according to the religious teachings about family dealings. Thus, they familiarize them with religious teachings. The researches indicate that the individuals raised in religious families are more likely to practice religious traditions.

W. Bradford Wilcox mentioned that socialization, solidarity, religious unity, and procreation are important mechanisms use to inculcate religiosity among individuals. ${ }^{18}$ Moreover, the children from the practiced religious families are more

\footnotetext{
${ }^{15}$ Margaret and Howard, Sociology: Understanding a Diverse Society (USA: Cengage Learning, 2007)

${ }^{16}$ A. Giddens, and S. Griffiths, Sociology Malden (Cambridge: Cambridge University Press, 2006)

${ }^{17}$ Penny Edgell, "In Rhetoric and Practice: Defining 'the Good Family in Local Congregations," Handbook of the Sociology of Religion (2003): 164-178.

${ }^{18}$ Helen Rose Ebaugh, (Ed.). Handbook of Religion and Social Institutions (Springer Science and Business Media, 2006).
}

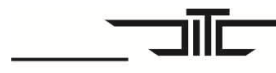

JOURNAL OF ISLAMIC THOUGHT AND CIVILIZATION 
likely to adopt religious traditions. ${ }^{19}$ Consequently, religious practices are not only an individual's free choice decision but a family's influence as well.

Along with family, neighbors are also not an ignorable component of social capital. After family, individuals have most frequent social interaction with their neighbors. The social capital generation is initiated with the greetings, exchange of domestic goods and taking care of neighbor's belongings in their absence. The developed trust among neighbours allows them to share their problems and seek solutions of these problems. So, this is the evidence of the presence of social capital. The walk able neighborhoods provides conducive environment for the fostering of social capital. The frequent social interaction encourages political and social engagement by increasing level of trust. ${ }^{20}$

Religion plays an important role in Pakistani society. People encourage congregational life like Namaz Ba Jamat, ${ }^{21}$ Khatam $^{22}$ and Milad ${ }^{23}$ at their homes. Considering the social, cultural and religious practices, neighborhood initiates interpersonal surveillance. They create parameters to judge the acts of inhabitants. Religiosity is one of these parameters. Religiosity plays vital role in developing individual's reputation among family and neighborhood. Hence, there is the proportional relation between religiosity and respect. People attempt to confine their acts in accordance to the opinion of neighborhood. The studies conducted by Baranowska, ${ }^{24}$ Montgomery and Casterline ${ }^{25}$ suggest that people try to avoid conflict and tend to make their life choices consistent with the norms and beliefs supported by the dominating religion in the neighborhood, even if they are not very religious themselves. Else people can face sanctions, ranging from oral communication to ostracism and exclusion from the social group. ${ }^{26}$ Thus, individuals' life choices are influenced by their social environment and social groups. The impact of sanctions

\footnotetext{
${ }^{19}$ Scott M. Myers, "An Interactive Model of Religiosity Inheritance: The Importance of Family Context," American Sociological Review (1996): 858-866; Darren E. Sherkat, "Religious Socialization: Sources of Influence and Influences of Agency," Handbook of the Sociology of Religion (2003): 151-163.

${ }^{20}$ Kevin M. Leyden, "Social Capital and the Built Environment: the Importance of Walkable Neighborhoods," American Journal of Public Health 93, no. 9 (2003): 1546-1551.

${ }^{21}$ Offering prayer in Mosque with a group of people

${ }^{22}$ Recite Qur'ānic verses by religious scholar and distribute eatables

${ }^{23}$ Singing hymns in the praise of last Prophet $(S A W)$ People are invited to attend the ceremony

${ }^{24}$ Anna Baranowska, Monika Mynarska, and Daniele Vignoli, A Dirty Look from the

Neighbors. Does Living in a Religious Neighborhood Prevent Cohabitation?. No. 71. Institute of Statistics and Demography, Warsaw School of Economics, 2014.

${ }^{25}$ Mark R. Montgomery, and John B. Casterline, "Social Learning, Social Influence, and new Models of Fertility," Population and Development Review 22 (1996): 151-175.

${ }^{26}$ Sylvia Keim, The Social Network Perspective, VS Verlagfür Sozialwissens chaften, 2011.
}

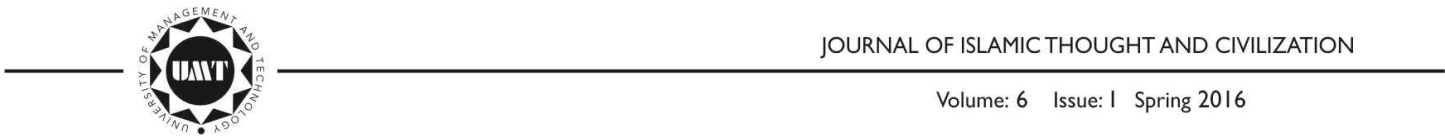


increases if the sanction is being imposed by close relations as friends and associates. $^{27}$

The conceptual framework of the current study is based upon the ideas of Halpern, ${ }^{28}$ Hazleton, Kennan ${ }^{29}$ and Uphoff. ${ }^{30}$ The sense of bonding and inclusiveness of social capital provides members with certain defined norms in accordance with the religion. Individuals follow the rules and behave according to their ascribed roles subsequent to the religious norms defined by their associations. These norms, role and rules are reinforced by sanctions or incentives. Thus, to attain and maintain an acceptable position in a group, human beings develop the strategies which are adapted to the needs of the social worlds that they inhabit. Moreover, a person try to learn what conditions make possible for them, and not to aspire to what is not available to them. The most improbable practices are therefore excluded, as unthinkable, by a kind of immediate submission to order that inclines individuals to make a virtue of necessity, that is, to refuse what is categorically denied and inevitable for its associations. Thus, it is an attempt to avoid sanctions in the form of isolation, exclusion and verbal criticism. This sense of belongingness creates social capital that can be distinguished as bonding capital (homogenous) and bridging capital (heterogeneous).

Fig 1: Model of Social Capital and Religiosity

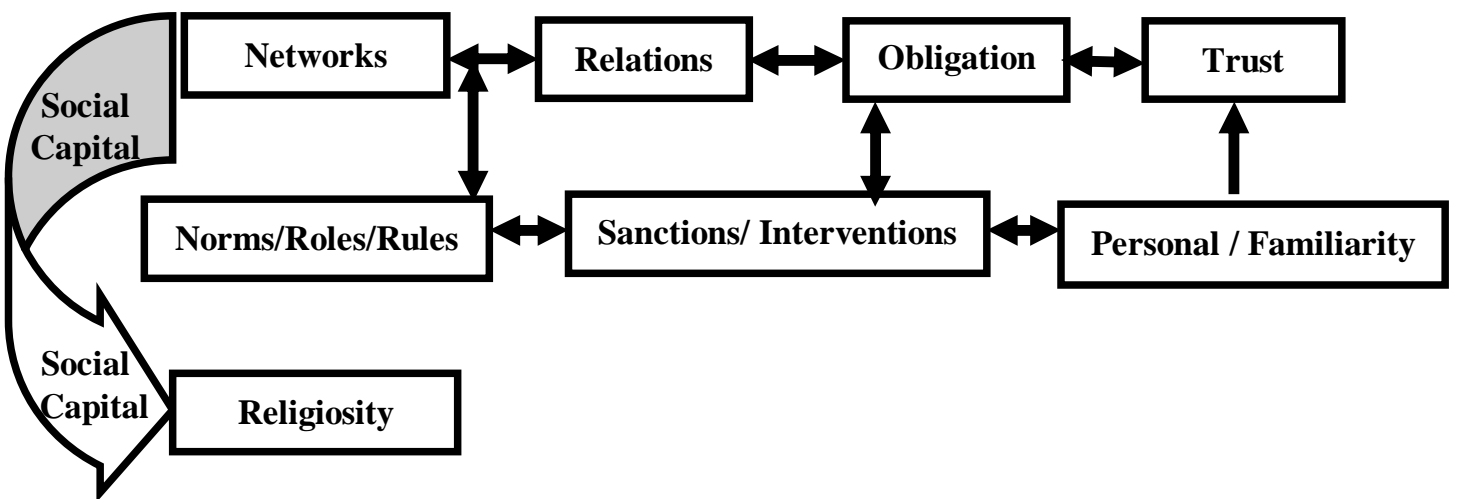

Source: Halpern (See note: 28), Hazleton (See note: 29) and Kennan (See note: 29), Uphoff (See note: 30 )

${ }^{27}$ Charles R. Tittle, Sanctions and Social Deviance: The Question of Deterrence (New York: Praeger, 1980).

${ }^{28}$ Diane F Halpern, "How Time-flexible Work Policies can Reduce Stress, Improve Health, and Save Money," Stress and Health 21, no. 3 (2005): 157-168.

${ }^{29}$ Vincent Hazleton, and Kennan William, "Social Capital: Reconceptualizing the Bottom Line," Corporate Communications: An International Journal 5, no. 2 (2000): 81-87.

${ }^{30}$ Norman Uphoff, and M. Wijayaratna Chandrasekera, "Demonstrated Benefits from Social Capital: the Productivity of Farmer Organizations in Gal Oya, Sri Lanka," World Development 28, no. 11 (2000): 1875-1890.

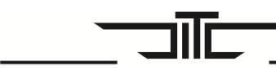

JOURNAL OF ISLAMIC THOUGHT AND CIVILIZATION 


\section{Methodology}

The qualitative study was conducted to explore association of social capital and religiosity of youth. The universe of the present study is comprised of educated youth of Lahore. To satisfy the objectives of study, population of the study includes 30 students from the departments of Social Sciences (Sociology, Psychology, Media, and Economics) at University of the Punjab. Data was collected using purposive sampling technique, as the aim of the study was to gain an in-depth understanding of the construction of religiosity in educated youth through social capital.

Twenty five in-depth interviews and 3 FGDs (Focus Group Discussions) were conducted to collect relevant data. The respondents were informed about the research. Their consent was taken. It was guaranteed that their names and identities would not be disclosed. Interview schedule was used. The data was collected in Urdu then, transcribed and translated in English. The data analysis was conducted through themes and narratives. Translation and Transliteration was conducted to get elaborative and unbiased results.

\section{Results and Discussion}

\subsection{Role of Culture and Environment; Divine Spirituality and the Dynamics of Gender}

Religion and culture are mutually exclusive categories. The notion of divine spirituality differentiates Religion and culture. The role of Religion at an ideological level and at a performance level is shaped by the culture and environment of the society.

Religion is taught to me by my family. I have never tried to study its teachings myself because I know that I have to follow society's parameters to perform religious activities.

The Religion as an ideology here referred to the belief system and the Religion as a performance referred to the actions and practices.

It was elaborated that the Belief is contextual and it precedes Action. The respondents gave mixed views about their belief system. They shared that it has become "impure" in the contemporary world. The faith has lost its essence and people are resorting to actions and practices only that lack the spiritual depth. They felt that their religion was making them inferior. As stated by respondents:

Religion is pure and helps individuals to make their souls pure. The purity comes with the concentration and connection with God. But unfortunately, this connection has lost due to undue interference of other people.

I understand that other than human dealings, religion is a personal matter. I am answerable to God for my prayers, fasting, Alms, pilgrimage etc. Therefore, I have no need to perform all these activities publically But if they were not practiced

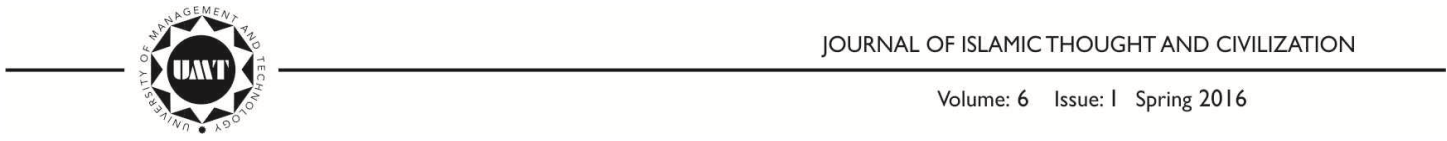


publically, people consider that we are not religious and good people. Hence, avoid social interaction.

As a boy, I feel that I am examined more than girls. My all activities, like hoteling, spending time with friends, coming home late at night are all associated with whether I offer prayers or not).

It suggests that religiosity and social capital is not a gender neutral term. On the other hand, the other school of thought was ethnocentric in terms of Religion. Here, they referred to their roots and origins and focused on the dire need of the time to push back themselves and the others towards the re-dressal of Religion.

\subsection{Role of Family}

The role of family is very crucial in spreading religiosity as a child imitates his/ her family and the family offers guidance in reciprocity. The environmental context for religious socialization is provided by family. Moreover, the role of Academia, Media and Peers in facilitating the religious sensitization and socialization process, alongside the normative structure of the Family is undeniable. The respondents cited certain events that acted as stimuli in swaying towards religion as an escape mechanism.

Family keeps us on religious track. They keep telling that religiosity can keep us connected with God and refrains many life hurdles coming our way.

It reflects the social control mechanism through rewards and punishments. Thus, it restricts freedom in performing religious practices. The respondents wanted to normalize themselves as the social realities around them were harsh. The respondents quoted two words when they were conceptualizing those who were not religious. They termed them 'Kharab' and they referred to them as 'khul gaye.' These words were used as a mocking resentment.

You can see my dressing. Though I am a boy, I like having long hair and wearing earrings. I have to face social isolation. Family and neighbors don't like me in family gatherings. They ask their kids to stay away from me. They consider me very fashionable and modern. They consider me astray with no moralities.

Dressing emerged as an important theme. It appeared as an assessment tool to test level of religiosity. The networks and associations of individuals really stress upon the dressing styles of individuals.

\subsection{Role of Madrassah as Perceived by Youth}

Madrassah is considered the epicenter of Religion and Cleric (Moulvi) is considered the Religious Leader. The metaphor of a pressure cooker was used with reference to the Madrassah.

Madrassah can play a vital role in child development. But it keeps suppressing individuals' need and necessities. It keeps on creating suffocation among individuals.

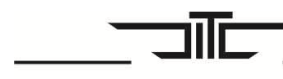

JOURNAL OF ISLAMIC THOUGHT AND CIVILIZATION

Volume: 6 Issue: I Spring 2016 
With the passage of time, people start feeling restless and pressurized. Then one day the pressure level rises and pressure cooker get's busted.

Mudrassah students have to follow the discipline of the institute as they don't want to be excluded from the social circle. They also have to face family pressure. But after passing out, sometimes they get involved in the negative social activities.

The respondents highlighted the lack of emotional development of a child there as Madrassah and the children have been subjected to stereotypical overgeneralization. The children are called for Qur'ānic recitations (Qur'ān Khawani) only. A Madraasah is usually termed as a hub of religious fundamentalism.

\subsection{Religious Practices}

The religious chanting at Milad ceremonies (Religious gathering glorifying the Last Prophet Muhammad $(S A W)$ was portrayed as an arena where there is interplay of money and religiosity. These ceremonies exhibit the pomp and show of the organizers and not their religiosity.

People make new dresses to attend these ceremonies. The Naat Khuwan (one who recites religious hymns) charged their decided rates. If it is religious and for the sake of God then why it is a pre-decided payment for them? Moreover, a box is placed in fornt of the recieter and guests are supposed to drop money in the box as a gift for $\mathrm{him} / \mathrm{her}$. The person who drops maximum money is considered having close association with God and His teachings.

The prayer (Namaz) is an amalgamation of social interaction and utility. The offering of the congregational Jumma prayer becomes a site of group collectivism.

Rather offering Jumma for your connection with Allah (SWT), it has become more of the social activity only. Our religion encourages social interaction, social cohesion and collectivism in the form of religious activities. But people have made them just a matter of social status. Sometimes, we attend Jumma to see teachers and management informally.

The performance of annual Hajj has become a matter of affectation. The critique of the character of 'Haji Saab' was discussed here who shows off his Hajj in gatherings."

People like to prefix Haji Saab in their names to show that they have performed Hajj. Moreover, people consider that a Hajji is superior and whatever he says is right. The respect level of an individual suddenly rises with this label. People start considering his words and opinions authentic over the religious and social matters, ignoring his overall dealings in financial matters and with his family.

Religion thus has - lost the internal derive and has been reduced to superficial things.

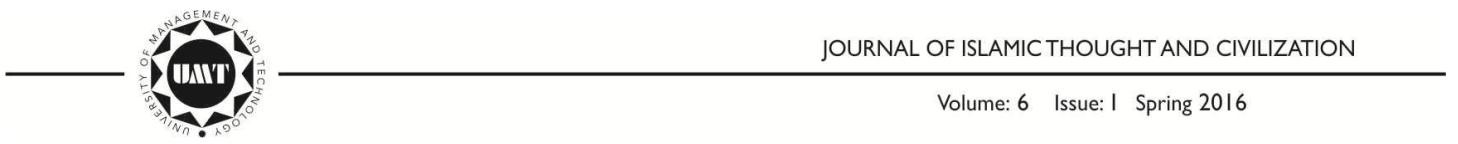




\title{
4.5. Religion as an Escape Mechanism: A Contested Concept
}

The respondents highlighted a very important Hadith, "Actions are judged by intentions," only to mention the dichotomy between appearance and reality in our society. They highlighted that people try to manipulate the Hadith to meet their vested interests, for their own escape mechanism or else of being judgmental to others.

\begin{abstract}
Social networks interference in the life of others has deteriorated the true meanings of the religion. People started manipulating religious teachings according to their own convenience. Social status has been attached with the performance of religious tasks. The religiosity acts as gate keeper to get access in a social group.

It's not like that we always perform religious task for others. But somewhere inside there is a social pressure, which reinforces to keep us aligned with the expectations of the people.
\end{abstract}

It is some kind of cognitive dissonance that is responsible for seeking an escape mechanism for better perception. It lends someone a positive reinforcement and a reasoning to satisfy oneself and others. The findings of the theory of the Looking Glass Self are applicable here. It is just like aligning a kid so that acts are adjusted according to the social environment.

\subsection{Religious Veil (Hijab)}

People consider Hijab as a symbol of Religious identity. But the respondents shared that females conception still ambiguous about the usage of Hijab.

I don't wear hijab so people consider me a kharab (characterless) girl. They think that I am an easy going person and any one can be my friend.

They are not sure about the teachings of religions about the veil. The lack of surety is fostering because there are two reasons for taking Hijab. At one end of the spectrum are the religious reasons with reference to the religious scripture, whereas, on the other end are the social reasons that includes social pressure, piety and to avoid harassment. Two of the valuable comments made by respondents were that Abaya has been commercialized in the Capitalist society and the other was that Abaya is adopted by choice and not by compulsion. The respondents concluded on the responsibility of the other gender (male) that if he practices (Haya) and guards his gaze, the females would automatically come under a Hijab.

\section{Conclusion}

The findings of the study suggest following framework for the intersection of social capital and religiosity.

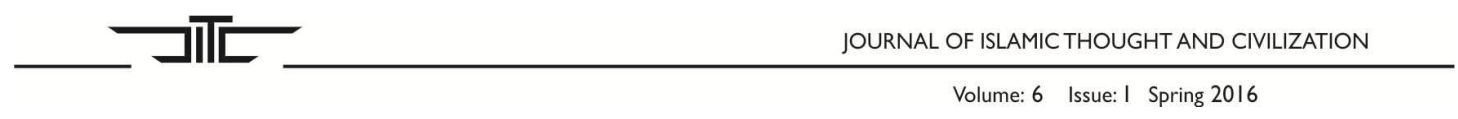




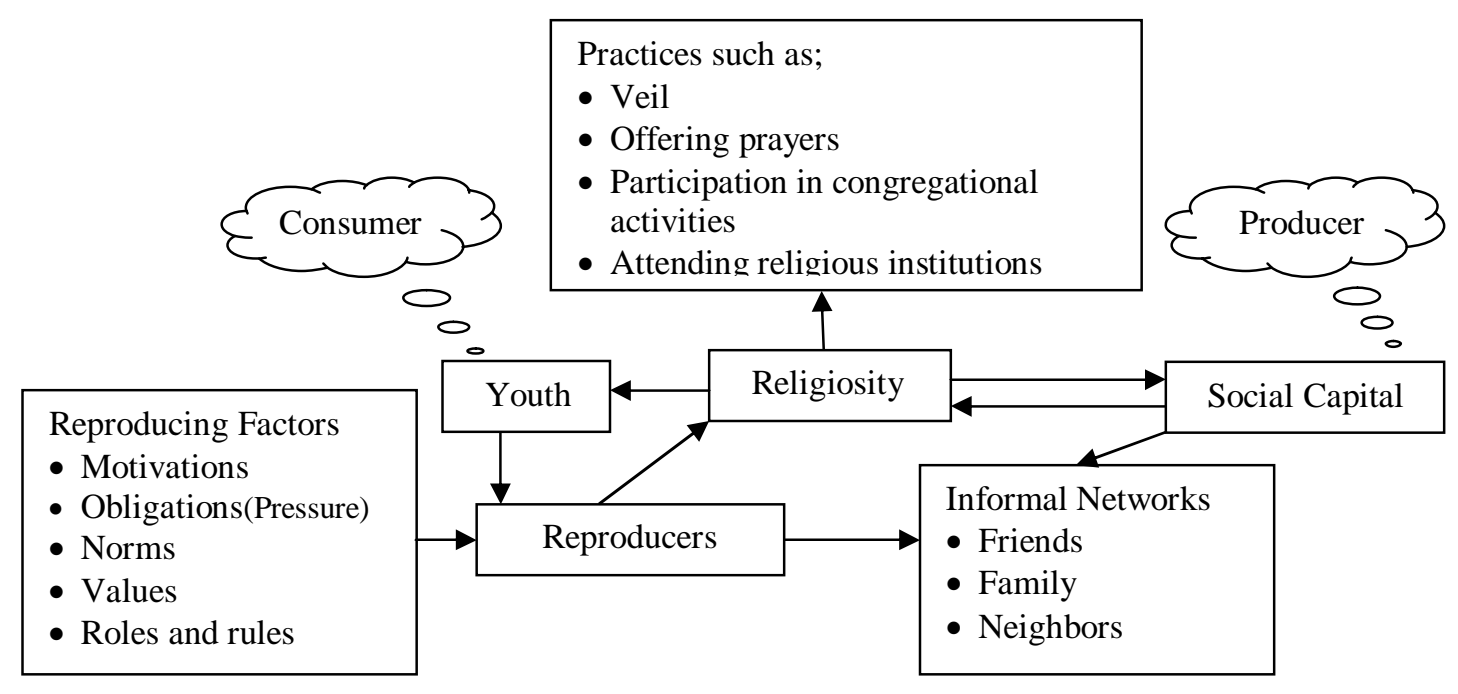

Pakistan is experiencing a youth bulge in terms of demography. This youth is unsure about the essence of Islam. The religiosity produced by family, peers and neighborhood is consumed by the youth. The responsibility of the reproduction of Religiosity lies in the hands of youth because of two reasons. One of the reasons is the age. The other reason is the level of motivation. Talking about the level of motivation, it should be noted that there are two kinds of motivation: Intrinsic and Extrinsic. Everybody cannot be motivated by Intrinsic factors as this is a benchmark of divine sublimity and can be portrayed through the Blessed Companions and Divine Religious Leaders (Walis and Auliya-e-Akaram). The extrinsic motivation is more human and it informs the common people. It includes social pressure in the form of 'Naseehat, Täkeed and Hidaya.' However, the motivation and pressure is now considered as a paradox. The motivation and pressure have become binary opposites now. The motivation provides solutions, an unconditional positive support and offer rewards and incentives. The pressure creates problems and renders punishments. Now, there is a difference of form and contents between the two constructs. To simplify, fear and interest offer a better alternative when elaborating the extrinsic factors of motivation of Religiosity among youth.

The level of reception of new knowledge is high in youth owing to their age, energy, abilities and cognitive tendencies, but they are clouded by other priorities. It should be noted that on the path of making our religion sacred, we have been practicing inclusion and exclusion. The youth have been victimized the most. The pressure is taking youth away from the true spirit of religion and inculcating restlessness among youth which being reflecting in the society as a whole. The same population will be part of the informal network. Therefore, tendency of repeating same attitudes increases.

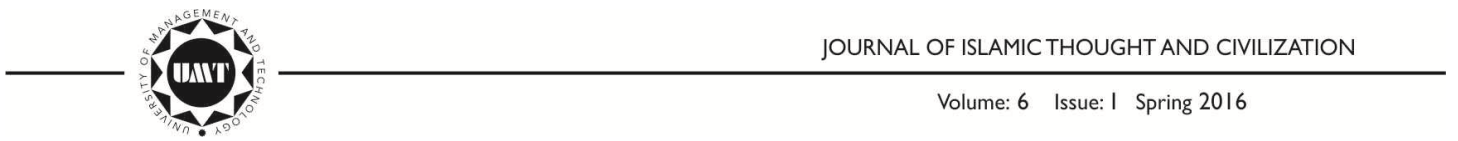


Gender emerged as one of the important theme. Neither religiosity nor social capital is gender neutral. The religion can be broadly categorized into two types of obligations namely; duties towards Allah (SWT) and duties towards Mankind. The society has merged both and has made individuals accountable to their social networks for their performance. The evaluating criteria are the practices that can be seen and then credited with the label of piousness or non-piousness. People have started wearing religion in their sleeves to make it noticeable for the sole purpose of social inclusion.

Resultantly, this could increase misinterpretation of religion and creating misconception about religious practices. This situation can lead to religious extremism of complete astray from the religious path. Therefore, conscious efforts are required by social actors and scholars in spreading the teachings of religion and encouraging religiosity among individuals. 


\section{BIBLIOGRAPHY}

Andersen, Margaret L. and Howard F. Taylor. Sociology: Understanding a Diverse Society. Updated. Cengage Learning, 2007.

Baranowska-Rataj, Anna. Monika Mynarska, and Daniele Vignoli. A Dirty Look from the Neighbors. Does Living in a Religious Neighborhood Prevent Cohabitation?. No. 71. Institute of Statistics and Demography, Warsaw School of Economics, 2014.

Becker, Penny Edgell. "In Rhetoric and Practice: Defining 'the Good Family' in Local Congregations." In Handbook of the Sociology of Religion. Edited by Michele Dillon. Cambridge University Press, 2003. 164-178.

Bourdieu, Pierre. "Social Space and Symbolic Power." Sociological theory 7, no. 1 (1989): 14-25.

Coleman, James S. "Social Capital in the Creation of Human Capital." American Journal of Sociology (1988): S95-S120.

Cornwall, Marie. Stan L. Albrecht, Perry H. Cunningham, and Brian L. Pitcher. "The Dimensions of Religiosity: A Conceptual Model with an Empirical Test." Review of Religious Research (1986): 226-244.

Cragun, Ryan. and Deborah Cragun. Introduction to Sociology. Blacksleet River, 2006.

Darder, Antonia. Culture and Difference: Critical Perspectives on the Bicultural Experience in the United States. Greenwood Publishing Group, 1995.

Ebaugh, Helen Rose. (ed.). Handbook of Religion and Social Institutions. Springer Science \& Business Media, 2006.

Grootaert, Christiaan, ed. Measuring Social Capital: An Integrated Questionnaire. No. 18. World Bank Publications, 2004.

Grootaert, Christiaan. and Thierry Van Bastelaer. eds. Understanding and Measuring Social Capital: A Multidisciplinary Tool for Practitioners. Vol.1. World Bank Publications, 2002.

Halpern, Diane F. "How Time-flexible Work Policies can Reduce Stress, Improve Health, and Save Money." Stress and Health 21, no. 3 (2005): 157-168.

Hazleton, Vincent and William Kennan. "Social Capital: Re-conceptualizing the Bottom Line." Corporate Communications: An International Journal 5, no. 2 (2000): 81-87.

Hirschi, Travis, and Michael J. Hindelang. "Intelligence and Delinquency: A Revisionist Review." American Sociological Review (1977): 571-587.

Hirschi, Travis. Causes of Delinquency. Transaction Publishers, 2002.

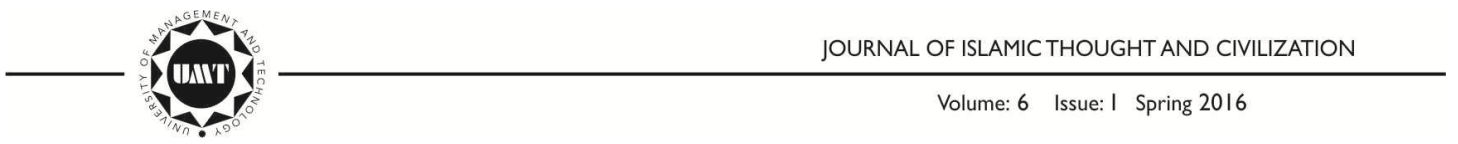


Hitt, Michael A., Ho-Uk Lee, and Emre Yucel. "The Importance of Social Capital to the Management of Multinational Enterprises: Relational Networks among Asian and Western Firms." Asia Pacific Journal of Management 19, no. 2-3 (2002): 353-372.

Khaldūn, Ibn. The Muqaddimah: an Introduction to History. Edited by Franz Rosenthal, and Nessim Joseph Dawood. No. 43. Princeton University Press, 1969.

Krishna, Anirudh, and Norman Uphoff. "Mapping and Measuring Social Capital through Assessment of Collective Action to Conserve and Develop Watersheds in Rajasthan, India." The Role of Social Capital in Development (2002): 85.

Leyden, Kevin M. "Social Capital and the Built Environment: the Importance of Walkable Neighborhoods." American Journal of Public Health 93, no. 9 (2003): 1546-1551.

Montgomery, Mark R., and John B. Casterline. "Social Learning, Social Influence, and New Models of Fertility." Population and Development Review 22 (1996): 151-175.

Myers, Scott M. "An Interactive Model of Religiosity Inheritance: The Importance of Family Context.” American Sociological Review (1996): 858-866.

Narayan, Deepa, and Michael F. Cassidy. "A Dimensional Approach to Measuring Social Capital: Development and Validation of a Social Capital Inventory."Current Sociology 49, no. 2 (2001): 59-102.

Putnam, Robert D., Robert Leonardi, and Raffaella Y. Nanetti. Making Democracy Work: Civic Traditions in Modern Italy. Princeton University Press, 1994.

Roof, W. C. "Concepts and Indicators of Religious Commitment: A Critical Review." The Religious Dimensions: New Directions in Quantitative Research. New York: Academic Press, 1979.

Sherkat, Darren E. "Religious Socialization: Sources of Influence and Influences of Agency." Handbook of the Sociology of Religion (2003): 151-163.

Stark, Rodney, and Charles Y. Glock. "The 'New Denominationalism.'”Review of Religious Research 7, no. 1 (1965): 8-17.

Stone, Wendy. "Measuring Social Capital."Australian Institute of Family Studies, Research Paper 24 (2001).

Swatos, William H. and Peter Kivisto. Encyclopedia of Religion and Society. Rowman Altamira, 1998.

Tittle, Charles R. Sanctions and Social Deviance: The Question of Deterrence. New York: Praeger, 1980.

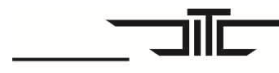

JOURNAL OF ISLAMIC THOUGHT AND CIVILIZATION

Volume: 6 Issue: I Spring 2016 
Torres, Benavides and Raquel Alicia. "An Interaction Model of Parents' and Adolescents' Influences on Mexican Adolescents' Intentions for Contraception and Condom Use.” ProQuest, 2007.

Uphoff, Norman, and Chandrasekera M. Wijayaratna. "Demonstrated Benefits from Social Capital: the Productivity of Farmer Organizations in Gal Oya, Sri Lanka." World Development 28, no. 11 (2000): 1875-1890.

Woolcock, Michael, and Deepa Narayan. "Social Capital: Implications for Development Theory, Research, and Policy." The World Bank Research Observer 15, no. 2 (2000): 225-249.

Yoo, David K. and Ruth H. Chung. "Religion and Spirituality in Korean America." (2009): 75-77. 